\title{
SELF-ACCEPTANCE AND SELF-CONCEPT AMONG TRANSGENDER IN INDONESIA
}

\author{
Reni Fitriani' ${ }^{1}$ Agni Laili Perdani², Lia Juniarni ${ }^{3}$
}

${ }^{1}$ Staff Nurse in Grand Mercure Clinic Bandung, Indonesia. Email: renifitriani55@gmail.com

2Lecturer in Nursing Study Program, Institute of Nursing Science, Indonesian Nurse Association (STIKep-PPNI)

West Java, Indonesia. Email: agni.perdani@gmail.com

${ }^{3}$ Lecturer in Nursing Study Program, Institute of Nursing Science, Indonesian Nurse Association (STIKep-PPNI)

West Java, Indonesia. Email: juniarnilia@yahoo.com

\section{ABSTRACT}

Background: Transgender is no longer classify a mental health illness from World Health Organization (WHO). The number of this community up to 3.9 million or $1.6 \%$ from Indonesia citizen. Transgender face social discrimination and stigma toward themselves as a result from community and family rejection. This condition could affected their process of self-acceptance and self-concept.

Purpose: This study aimed to describe the self-acceptance and the self-concept among transgender in Indonesia

Methods: A cross-sectional study was conducted in transgender community at Srikandi Pamungkas, Lembang. This study used a convinience sampling and 30 respondents agreed to participate. Data was collected using selfquestionnaire and consist of 52 item questions with.

Results: This study showed that the total of transgender with good self-acceptance is $17(56.7 \%)$ and good selfconcept is $16(53.3 \%)$

Conclusion: Most of the transgender in the transgender community had good self-acceptance and good selfconcept from the support system in community environment.

\section{Keywords : Self-concept, self-acceptance, transgender}

\section{INTRODUCTION}

Gender dysphoria or gender incongruence is an internal conflict in a person sexual status with gender identity by several experienced problems including uncomfortable with their own body, difficulties to express their gender and self-image distress (APA, 2016). World Health Organization (WHO) no longer classify this was a mental health illness and used term transgender or people with different gender identity from assigned sex (WHO, 2016). The total number of this third sex aged above 14 years is 9.5 million people in 2010 (Winter, 2012). Furthermore, data from Indonesia Transgender Communication Forum showed that 3.9 million transgender lived or $1.6 \%$ from Indonesia citizen. This number reached up to 32.065 in 2010 and the total number in West Java Province is 2,107 (Ministry of Health, 2010) where Bandung is the three largest of transgender population. Thirty people lived in Lembang Subdistrict according to data obtained from The Chairperson of Transgender Community. This place is the central location where they usually gathered together and held several transgender festivals.

Based on religious and cultural believe transgender considered as something unnatural because of the behavior shown by changing the appearance of men to women or vice versa and even to change sexes. Psychology theory (Sugeng,

2008) define that among transgender the physical assigned is a man but deep within his soul is a woman. It is inevitable to say that the stigma and discrimination received by transgender caused them to face the rejection from the environment and the adaptation process affected the process of self-acceptance. Selfacceptance is a form of self-assessment and appreciation and during a process similar to selfconcept (Huclock, 2008).

Adaptation to social pressure is a common problem among transgender to build their selfacceptance. According to Hurlock (2008) selfacceptance is a level of ability and desire of individuals to live with all the characteristics of themselves. Individuals who can accept themselves are interpreted as individuals who do not have problems with themselves. Transgender also have a burden of feeling towards themselves to gain their self-concept. Self-concept is the perception of someone to their self, feelings, beliefs, and values (Desmita 2010). From the description above, this study aimed was to 
describe the self-acceptance and the self-concept among transgender in Indonesia.

\section{RESEARCH METHODS}

This is a cross-sectional study with convenience sampling and was conducted in the transgender community at Srikandi Pamungkas, Lembang. Thirty respondents agreed to participate in this study. Data was collected using self-questionnaire developed from Stuart (2016) and Hurlock (1974). After informed consent was obtained, the respondents asked to filled the questionnaire consist of 52 item questions with Likert Scale (0-3). The positive and negative statement consists of 26 items questions, respectively. A pilot study was conducted among 20 respondents with the good result of validity and reliability.

\section{RESEARCH RESULTS}

Table 1. Demographic Characteristics ( $\mathrm{N}=30)$

\begin{tabular}{lc}
\hline Variables & $\mathrm{N}(\%)$ \\
\hline Age & \\
$18-25$ & $16(53.2)$ \\
$26-40$ & $8(26.6)$ \\
$>40$ & $6(20.2)$ \\
Education & \\
Elementary School & $5(16.7)$ \\
Junior High School & $13(43.3)$ \\
Senior High School & $12(40.0)$ \\
\hline
\end{tabular}

Table 2. Self-Acceptance Among Transgender $(\mathrm{N}=30)$

\begin{tabular}{cc}
\hline Categories & $\mathrm{N}(\%)$ \\
\hline Good & $17(56.7)$ \\
Poor & $13(43.3)$ \\
\hline
\end{tabular}

Table 3. Self-Concept Among Transgender $(\mathrm{N}=30)$

\begin{tabular}{cc}
\hline Categories & $\mathrm{N}(\%)$ \\
\hline Good & $16(53.3)$ \\
Poor & $14(46.7)$ \\
\hline
\end{tabular}

More than a half $(53.2 \%)$ of the transgender aged 18-25 and majority of them obtained education above elementary school (Table 1). Out of 30 respondents, $17(56.7 \%)$ of them had good selfacceptance (Table 2), and 16 transgender (53.3\%) also showed the good self-concept (Table 3 )

\section{DISCUSSION}

The results of this study indicate more than an half respondents had good self-acceptance and self-concept. It could be said that the transgender can accept and understand about themselves and received all the experience. This understanding starts from being confident with himself and honest with the facts that they likes to fantasize. Transgender stated that they feels happy and not feel under pressure by his current situation or conditions. According to Germer (2009), the stages of self-acceptance consist of five phases. Transgender declared that community is the most significant factor for influence them in the initial period. From the beginning, they face avoidance because the displeasure from that environment that they consider is abnormal. The next is a defensive strategy to keep them in the environment. After going through a period of avoidance, these individuals experience a sense of curiosity about the situation they are facing so they want to learn more about the world of transgender even though this makes them feel anxious. Eventually, they make an individual judgment and self-acceptance. The good of self-concept in transgender because they are not closing themselves with people around, easy to get along with, adjust to the environment, and had high selfesteem. Respondents stated that they gained the support of the people around him, often participate in community activities, and had high selfconfidence thus they not feel embarrassed to show his current situation.

The average respondent who has a good selfconcept is adolescent. According to Santrock (2002) adolescence is a period where individuals are looking for self-identity and develop to accept physical state and achieve social roles as men or women. For adolescent transgender, this social role was not achieved therefore they change to behavior deviation because of the background of

Reni Fitriani' Staff Nurse in Grand Mercure Clinic Bandung, Indonesia. Email: renifitriani55@gmail.com Agni Laili Perdani ${ }^{2}$ Lecturer in Nursing Study Program, Institute of Nursing Science, Indonesian Nurse Association (STIKep-PPNI) West Java, Indonesia. Email: agni.perdani@gmail.com

Lia Juniarni ${ }^{3}$ Lecturer in Nursing Study Program, Institute of Nursing Science, Indonesian Nurse Association (STIKep-PPNI) West Java, Indonesia. Email: juniarnilia@yahoo.com 
the unpleasant childhood. Poor childhood experience like lack of love from parents or inadequate family conditions influence their decision to become transgender. Also, the absence of understanding between parents and children, less harmony between father \& mother and parents demands for children's behavior lead them to a low self-concept (Coopersmith,1995)

\section{CONCLUSION AND SUGGESTION}

The results of this study showed that more than a half transgender had good selfacceptance and good self-concept. They can accept and understand themselves. Several factors contributed including support system from society and less discrimination toward them. They feel confident to express their true identity and happy with their current life. People in their neighborhood asked them to participate in community activity. Based on this study, the authors suggest in the next research is to analyze the relationship between self-acceptance and self-concept with larger sample size.

\section{REFERENCES}

American Psychiatric Association (APA). (2016). What Is Gender Dysphoria?. Retrieved January 20, 2019 from https://www.psychiatry.org/patientsfamilies/gender-dysphoria/what-is-genderdysphoria

Arfanda. (2015). Konstruksi sosial masyarakat terhadap waria.Bandung: pionir jaya.

Coopersmith. (1995). The Antecendents of Self Esteem. San Fransisco: W. H Freeman And Company.
Desmita. (2010). Psikologi perkembangan. Bandung: Remaja Rosdakarya.

Germer. (2009). The Mindful path of selfcompassion. united state of america: the guilford press.

Hurlock. (2008). Psikologi perkembangan. jakarta: erlangga press.

Kementrian Kesehatan Republik Indonesia. (2010). Profil kesehatan indonesia. jakarta: kementrian kesehatan Rl.

Nursalam. (2015). Konsep penerapan metode penelitian ilmu keperawatan. jakarta: salemba medika.

Riyanto, A. (2013). Statistik inferensial untuk analisa data kesehatan. jakarta: nuha medika.

Santrock, J. W (2002). Perkembangan masa hidup: life-span development. Jilid II (5 $5^{\text {nd }}$ ed). Jakarta: Erlangga

Sugeng, P. (2008). Waria dan tekanan sosial. malang: UMM Press.

World Health Organizaton (WHO). 2016. Growing recognition of transgender health. Retrieved January, $20, \quad 2019$ from https://www.who.int/bulletin/volumes/94/11/16$\underline{\text { 021116.pdf }}$

Whitbourne, H. (2010). Psikologi abnormal. jakarta: salemba.

Reni Fitriani' Staff Nurse in Grand Mercure Clinic Bandung, Indonesia. Email: renifitriani55@gmail.com Agni Laili Perdani ${ }^{2}$ Lecturer in Nursing Study Program, Institute of Nursing Science, Indonesian Nurse Association (STIKep-PPNI) West Java, Indonesia. Email: agni.perdani@gmail.com

Lia Juniarni ${ }^{3}$ Lecturer in Nursing Study Program, Institute of Nursing Science, Indonesian Nurse Association (STIKep-PPNI) West Java, Indonesia. Email: juniarnilia@yahoo.com 